\title{
INVESTAVIMO STRATEGIJŲ TAIKYMAS KAPITALO RINKOJE
}

\author{
Grigorij ŽILINSKIJ, Monika GEIGAL* \\ Vilniaus Gedimino technikos universitetas, Verslo ir vadybos fakultetas, \\ Finansu inžinerijos katedra, Saulètekio al. 11, LT-10223, Vilnius, Lietuva \\ *El.paštasmonika.geigal@stud.vgtu.lt
}

\begin{abstract}
Santrauka. Straipsnyje nagrinėjama investavimo sąvoka bei pasiūlius jos apibendrinantị apibrèžimą, pateikiama investavimo klasifikacija, nurodomi investuotojų tipai. Akcentuojama, jog pradedantieji investuotojai j̨žengdami ị finansų pasaulị ir bandydami jị suprasti, susiduria su daugybe informacijos, kuri dažnai būna prieštaringa. Tokiems asmenims tampa sudètinga priimti racionalius sprendimus, todèl išskiriama aktyvi ir pasyvi investavimo strategija, aprašomi šių strategijų privalumai bei trūkumai. Investicijų procesą reglamentuoja du itin svarbūs aspektai - investicijų grąža ir rizika, todèl investuojant būtina sukurti specialų veiksmų algoritmą tikslo nustatymas, situacijos ịvertinimas, resursų apskaičiavimas, galimų alternatyvų paieška. Manoma, kad investuotojų elgseną galima pagrịsti elgsenos finansų teorija, kuri šiuolaikiniame pasaulyje turi vis didesnę reikšmę. Atitinkamai, svarbu atsižvelgti ị investuotojų poreikius ir finansines galimybes, todèl tyrimui atrinkti trys daugiakriteriniai vertinimo metodai SAW, TOPSIS ir VIKOR Naudojant šiuos metodus vadovaujamasi pasyvia investavimo strategija, o pasiekti rezultatai nurodo, kad pelningiausia investicija - Skyworks Solution akcijas, todèl formuojant akcijų portfelį jas reikètų ịtraukti pirmiausia.
\end{abstract}

Reikšminiai žodžiai: investicijų portfelis, kapitalo rinka, investavimo strategijos, aktyvus investavimas, pasyvus investavimas, daugiakriteriniai metodai, sprendimo alternatyvos.

\section{Ivadas}

Tyrimo aktualumas. Prasidejjus sparčiam pasaulio finansinių rinkų vystymuisi, žmonių, besidominančių investicijomis, skaičius drastiškai išaugo. Iki šiol Lietuvoje privatūs investuotojai galèjo investuoti į užsienio rinkas tik per specializuotas finansines ịstaigas, kurios investuotojams suteikdavo galimybę atlikti operacijų pavedimus, sudarytas užsienio biržose. Brokerių oferta buvo ribota, o privatus investuotojas turejo prisiimti gana aukštus komisinius ir sutikti su suteiktų paslaugų žema kokybe. Investuojant Europos kapitalo rinkoje buvo susiduriama su nepakankama tiesiogine prieiga prie jos, teisiniais apribojimais (pvz., užsienio valiutos operacijos), specializuota informacijos stoka bei užsienio teisès nežinojimu. Žvelgiant iš šiandienos perspektyvos, investuotojų padètis smarkiai pasikeitè. To priežastimi tapo šiuolaikinių informacinių technologijų plètra, suteikianti galimybę lengvai surasti ir įsisavinti reikalingą informaciją. Ekonominis nestabilumas bei sparčiai didejjanti konkurencija finansų rinkoje skatina asmenis semtis investavimo idèjų. Lietuvos investuotojai dabar turi didelị pasirinkimą tarp daugybę naujų rinkų, kuriose prekiaujama pasaulio kompanijų akcijomis ar obligacijomis, o taip pat ir naujų būdų kur investuoti savo santaupas, kas buvo neprieinama prieš keliolika metų. Pagrindinis investuotojo sprendimo investuoti motyvas gauti pakankamai pajamų iš savo investuoto kapitalo. Nors tikslas atrodo visiškai akivaizdus, jo pasiekimas nėra toks aiškus dèl rizikos, susijusios su investicijomis kapitalo rinkoje. Manoma, kad investavimo strategijos kapitalo rinkoje yra vienos iš sudetingiausių tarp bet kokių ekonominiu sprendimų. To priežastimi yra ịvairūs veiksniai, turintys įtakos ekonominei padéčiai vertybinių popierių emitentų šioje rinkoje. Paprastai susiduriama su infliacijos rizika, kuri susijusi su kapitalo perkamosios galios sumažejimu. Tokiu atveju, investicinės pajamos turètų tinkamai kompensuoti pinigų perkamosios galios sumažèjimą. Nors investicijos ị kapitalo rinką laikomos rizikingomis, tačiau jos suteikia progą pasipelnyti ir diferencijuoti rizikos mastą priklausomai nuo to, kokio tipo investavimo instrumentai (vertybiniai popieriai) bei kokia investavimo strategija bus parinkta. Daugelyje realaus investicinio pasaulio situacijų, dažniausiai sprendimus priimantys asmenys, t. y. investicinių portfelių valdytojai, susiduria su eile kriterijų, ị kuriuos vertètų atsižvelgti anksčiau priimant bet kokị sprendimą investuoti pinigus. Tam sukurti sprendimų priemimo pagal daugelį kriteriju (MCDM) metodai, kurių tikslas - pasirinkti tinkamiausią sprendimą iš prieinamu alternatyvų. Šiuo straipsniu bus siekiama parodyti kaip pasirinkti geriausią investavimo instrumentą (vertybinius popierius), remiantis daugiakriteriniais metodais, suformuoti optimalų akcijų portfelį bei apžvelgti kokie veiksniai gali paveikti investuotojų elgseną. 
Tyrimo problema. Kaip atsižvelgiant i investuotojų poreikius ir finansines galimybes, remiantis daugiakriteriniais metodais, pasirinkti pelningiausią investavimo instrumentą.

Tyrimo objektas. Investavimo strategijos. portfeli.

Tyrimo tikslas. Išanalizavus investavimo modelius, pasirinkti vieną pelningiausią algoritmą, sudarant akcijų

Tikslui pasiekti iškelti šie $u z ̌ d a v i n i a i$ :

- Išanalizuoti mokslinèje literatūroje nagrinèjamų investavimo strategijų teorinius aspektus.

- Pasitelkiant daugiakriterinius metodus, parodyti kaip jų pagalba, pasirinkti patraukliausią investicinių instrumentų alternatyvą.

- Remiantis tyrimo gautais rezultatais, pademonstruoti daugiakriterinių metodų sąryšị.

\section{Investavimo ir strategijų teorinė analizė}

Investicijų procesas atlieka svarbų vaidmenį bet kurios šalies ekonomikoje. Investicijos didžiaja dalimi lemia ekonominị valstybès augimą, laikomos esminiu pagrindu, kuriuo grindžiamas visuomenès ekonominis vystymasis. Tai viena iš pagrindinių žmogaus veiklos sričių ekonomikoje, siekianti išsaugoti ir padidinti esamų pinigų vertę. Pagal Bodie et al. (2012) investicijos - einamasis piniginis ar kitų išteklių ịsipareigojimas, tikintis gauti naudos ateityje. Valentavičius (2010) investicijas apibūdina kaip priemonę į kurią gali būti įdètos lèšos viliantis, kad ji duos teigiamas pajamas ir dar išaugs arba padidins savo vertę. Atlygis arba pelnas iš investicijų gaunamas dviem pagrindinėmis formomis: dabartinėmis ịplaukomis (pajamomis) arba padidejjusia verte. Valakevičiaus (2008) teigimu, investicija yra šiandieninès vertès (pinigų ar kitų kapitalinių išteklių) aukojimas perkant realujj turtą ar vertybinius popierius, tikintis ateityje gauti didesnę vertę, proporcingą prisiimtai rizikai. Taigi susumuojant autorių žodžius - investicijos suprantamos kaip nuolatinis lěšų panaudojimas siekiant didesnès grąžos ir pelno gavimo ilguoju laikotarpiu.

Mokslinèje literatūroje išskiriami du investuotojų tipai: individualūs ir instituciniai investuotojai. Individualūs investuotojai dar kartais vadinami smulkiaisiais investuotojais, patys pasirenka ị kuriuos finansinius instrumentus vertètų investuoti savo lěšas. Prie institucinių investuotojų priskiriami komerciniai bankai, draudimo kompanijos, pensijų fondai bei kitos finansinès institucijos. Kapitalo rinka dažniausiai skirstoma pagal tai ar instrumentuose yra užtikrintas pastovus pinigų srautas arba siūlo dalyvauti būsimame įmonès pelne. Šiuo atveju kalbame apie fiksuotų pajamingumo bei nuosavybès instrumentus. Tam, kad geriau suprastumème pati investavimo procesą bei jo strategijas, investicijos klasifikuojamos pagal objekta (realios, investicijos ị vertybinių popierių portfeli, dviejų investavimo būdų); tipa (tiesioginès ir netiesioginès); termina (trumpalaikès, vidutinio laikotarpio, ilgalaikès), pelningumo laipsnị (Zaytseva, 2014). Dabartiniu metu ekonomikoje yra paplitusių nemažai investavimo būdų, kurie yra prieinami bet kurio tipo investuotojui. Tiek pradedantysis, tiek jau pažengęs investuotojas norint sudaryti investicinị portfelị turi apmąstyti ị kokias priemones investuoti, kokiomis dalimis paskirstyti savo lèšas, kokią riziką ir kada ją prisiimti (Kiyak, 2014).

Tam, kad nustatyti optimalią kapitalo investavimo kryptị, yra būtinas investavimo strategijos kūrimas ir sẻkmingas jos įgyvendinimas. Investavimo strategija - laisvų lěšų investavimas siekiant maksimalaus pelningumo bei užtikrinant priimtiną rizikos laipsnį (Nayman, 2009). Norint išvengti iracionalių sprendimų, vertėtų investavimo sąlygas paruošti iš anksto. Kiekvienas investuotojas, atsižvelgdamas i savo finansini potencialą, požiūrị i galimą riziką, pasirenka sau palankiausią investavimo strategiją. Investicijų strategijos kūrimas visada grindžiamas investicijų grąžos, investavimo laiko ir susijusios rizikos analize. Šie veiksniai lemia investicijų i tam tikrą kapitalo rinkos instrumentą, efektyvumą. Gintaro Černiaus (2013) teigimu prieš investuojant reikètų iškelti tikslą, kuris būtų suformuluotas išsamiai ir suprantamai. Taip pat galima pažymèti reikalingą sumą tikslo igyvendinimui bei laikotarpí, per kurị norima sukaupti lèšas. Po tikslo nustatymo naudinga atkreipti dèmesị ị esamą situaciją kapitalo rinkose ir padaryti atitinkamas išvadas. Sekantis žingsnis tai išteklių numatymas ir konkretus apskaičiavimas kiek mums prireiktų finansinių resursų tikslo igyvendinimui. Norint sudaryti planą konkrečiam finansiniam tikslui, turime atsižvelgti į galimas alternatyvas.

Kalbant apie investavimo strategijas, vertètų pabrėžti, jog pirmiausia, siekiama maksimaliai didinti investicijų grąžą, mažinant kartu investicijų naudojamų išteklių vertę bei pirkimo-pardavimo sandorių kaštus. Iprasta, kad pasirenkami didžiausią grąžą užtikrinantys investavimo variantai, nors dažnai atkreipiamas dèmesys ir ị rizikos investicijos laipsnị. Nusprendus investuoti turimą kapitalą, visada reikia atsižvelgti i du kiekvienai investicijai būdingus parametrus - numatomą grąžos normą ir su ja susijusią riziką. Diversifikacijos efektas tai viena iš investicinio portfelio rizikos savybių, o pagrindinis diversifikavimo tikslas yra sumažinti rizikos dydį. Investicijų diversifikavimo terminas pirmą kartą atsirado Harry Markowitz (1952) paskelbtame straipsnyje apie portfelio teoriją, už kurị autorius gavo Nobelio premiją. Pagrindinėje autoriaus tezèje įvestas naujas elementas sprendimų prièmimo procese - investicijų saugumas. Amerikos ekonomistas Markowitz pasiūlè ieškoti investicijų, kurios ne tik duotų siekiamo pelno, bet ir sumažintų finansinę riziką. Savo darbe pirmą kartą mokslininkas panaudojo portfelio rizikos, pelningumo, diversifikavimo ir efektyvumo sąvokas. Kalbant apie portfelị, sudarytą tik iš akcijų, diversifikavimo nuostatas pateiké sekantis Nobelio premijos laureatas - William Sharpe (1970). Remiantis jo 
prielaidomis, siekiant mažinti riziką, pagrindinis vaidmuo tenka akcijų atrankoms, turinčioms skirtingus grąžos koreliacijos koeficientus (Suresh ir Harshitha, 2017). Ilgą laiką vyravo ịsitikinimas, jog Markowitz modelis geriausiai apibūdinana investuotojų elgesi akcijų rinkoje. Vieno indekso modelis buvo traktuojamas kaip didelis apytikslis metodas, kuris užtikrina paprastumą ir operatyvumą. Niranjan (2013) teigè, kad sukurti ir investuoti i optimalų investicinị portfelị daug lengviau ir patogiau naudojant Sharpe pasiūlytą modelį, kadangi šis modelis nustato vertybinių popierių riziką (aišku jeigu vertybiniai popieriai yra gerai diversifikuoti). Isitikinimui, jis atliko tyrimą bei prièjo prie išvadų, kad Sharpe modelis yra tinkamiausias portfelio rizikai apskaičiuoti. Kadangi siekiant nustatyti portfelio riziką, Markowitz modeliui reikia akcijų kovariacijų apskaičiavimo, o kuo daugiau turime akcijų, tuo daugiau turime atlikti skaičiavimų. Minètų mokslininkų teorinė raida neịkainojamai prisidèjo prie investicijų teorijos ir investavimo politikos formavimo praktikos plètojimo, tačiau vykstančios diskusijos ir praktika ịrodo šios problemos tyrimų neužbaigtumą bei jų tęsimo svarbą.

Pasak Keynes'o, (rinkoje žinomas ne tik kaip teorinis ekonomistas, bet ir sėkmingas investuotojas), kuo patrauklesnė tampa kapitalo rinka, tuo daugiau ị rinką patenka neprofesionalių, emocijomis paremtų dalyvių. Labai svarbu išnagrinèti ir suprasti investuotojų elgseną ir pasinaudojus rinkos informacija formuoti savo investavimo strategiją. Iš esmès kalba eina apie aktyvų ir pasyvų rinkos dalyvių elgesį (Teplova, 2011).

Aktyvaus investavimo strategija pasireiškia periodiškai koreguojant portfelio sudètį, perkant ir parduodant vertybinius popierius, atsižvelgiant $\mathfrak{i}$ akcijų judejjimą rinkoje. Ši schema yra pati sudètingiausia, nes reikalauja ne tik daug analitinio darbo, pagristo nuolat gaunama ir apdorojama kapitalo rinkos informacija, bet ir brangiomis techninėmis sistemomis bei technologijomis, užtikrinančiomis informacijos gavimą iš rinkos ir apdorojimą realiu laiku. Aktyvus portfelio valdymas yra brangiausias investavimo variantas, nes investuotojui aktyvaus portfelio valdymo galimybę labai apriboja sąnaudos, kuriuos generuoja informacijos tiekejjai ir analitikai. Todèl šia schema, kaip taisyklè, vadovaujasi didelès investicinès bendrovès, bankai, tarpininkai ir kiti specialistai, turintys specialius analitinius skyrius bei pakankamai pinigų. Ši strategija numato, jog dèka aktyvių vertybinių popierių pirkimo pardavimo operacijų galima maksimizuoti pelną. Pasyvios strategijos esmè tame, kad investuotojas ịsigyja vertybinius popierius ir juos laiko iki tinkamo laikotarpio. Veikdamas principu ,nusipirk ir laikyk“ (buy and hold) investuotojas atidžiai pasirenka akcijas pirkimui, kurios jo manymu ateityje atneš didesnę grąžą (Wells Fargo Bank, 2019). Renkantis emitento vertybinị popierių, pirmiausia, atsižvelgiama į jo turimą augimo potencialą. Taigi, iškyla klausimas kurį metodą geriausiai taikyti - aktyvų ar pasyvų norint siekti sėkmingo investavimo? Kiekvienas metodas turi savo privalumų ir trūkumų, apžvelkime juos (1 lentelè):

1 lentelè. Aktyvaus ir pasyvaus investavimo metodo privalumai bei trūkumai (sudaryta autorių, remiantis Wells Fargo Bank, 2019)

\begin{tabular}{|l|l|l|l|}
\hline \multicolumn{2}{|c|}{ Aktyvusis investavimo metodas } & \multicolumn{1}{c|}{ Pasyvusis investavimo metodas } \\
\hline \multicolumn{1}{|c|}{ Privalumai } & \multicolumn{1}{c|}{ Trūkumai } & \multicolumn{1}{c|}{ Privalumai } & \multicolumn{1}{c|}{ Trūkumai } \\
\hline $\begin{array}{l}\text { Galimybe gauti grąžą ne tik } \\
\text { patiriant akcijų atsigavimą bet ir } \\
\text { nuosmuki }\end{array}$ & $\begin{array}{l}\text { Portfelio valdymo } \\
\text { dideli komisiniai }\end{array}$ & $\begin{array}{l}\text { Mažos valdymo } \\
\text { išlaidos bei jo } \\
\text { paprastumas }\end{array}$ & $\begin{array}{l}\text { Nuo indekso priklauso } \\
\text { investavimo rezultatai }\end{array}$ \\
\hline $\begin{array}{l}\text { Investuoto kapitalo aukšta } \\
\text { grąža (palyginus su } \\
\text { pasyviu) }\end{array}$ & $\begin{array}{l}\text { Didesni komisiniai } \\
\text { ant trumpų akcijų } \\
\text { pozicijų }\end{array}$ & $\begin{array}{l}\text { Gerai diversifikuotas } \\
\text { portfelis }\end{array}$ & Kontrolès stoka \\
\hline $\begin{array}{l}\text { Galimybe išvengti VP } \\
\text { portfelio nuvertėjimo } \\
\text { rinkos kritimo metu }\end{array}$ & $\begin{array}{l}\text { Portfelio valdymo } \\
\text { didelès laiko } \\
\text { sąnaudos }\end{array}$ & $\begin{array}{l}\text { Akcijų portfelis } \\
\text { nereikalauja dažnaus } \\
\text { pertvarkymo }\end{array}$ & $\begin{array}{l}\text { Ekonominès krizès metu, } \\
\text { drastiškas VP portfelio } \\
\text { vertės kritimas }\end{array}$ \\
\hline
\end{tabular}

Aktyvios investavimo strategijos šalininkai tiki, kad geresnių rezultatų galima sulaukti esant rinkos svyravimams. Tuo tarpu pasyvios investavimo strategijos dalyviai tiki gauti daugiau grąžos iš ilgalaikių investicijų $i$ finansinius instrumentus. Patyrę investuotojai gali efektyviai kontroliuoti savo investicini portfeli bei sekdami indekso grąžą gali pasiekti geresnių rezultatų. Tam, kad kiekvienu konkrečiu atveju būtų pasiekta tikrai efektyvi investavimo strategija dabartinejje vertybinių popierių rinkoje, sandorių su vertybiniais popieriais modeliavimas turètų užtikrinti optimalų akcijų ir kitų vertybinių popierių investicinio portfelio sudėtị.

Akcijos neturi absoliučios tikrosios vertès. Jų kaina nuolat juda ir tam, kad nustatyti patikimą vertinimo diapazoną, reikalauja tikslių metodų. Žinomas investuotojas Jim Cramer savo knygoje „Mad Money“ yra pasisakęs - reikia žinoti ką valdai. Profesionaliai parinktas akcijų portfelis, rinkos leidžia išvengti ,paniško“ akcijų išpardavimo ir rinkos svyravimų, t. y. rinkos kainų kritimo metu. Garsios CANSLIM investavimo strategijos kūrèjas, žinomas investuotojas William J. O’Neil, savo akcijų pasirinkimo metodologijoje rašè, jog neverta pirkti akcijų dèl išmokamų dividendų dydžio ar akcijos kainos ir pelno santykio, verta pirkti kompanijos - lyderès akcijas, atsižvelgiant i jos pardavimų bei pelno augimo tempus, produktų ir paslaugų kokybę. Viena iš situacijų, kada investuotojui reikia rinktis iš kelių akcijų, kaip tai rodoma šiame darbe, visai kitaip problema atrodo, kai reikia lyginti ir vertinti keliasdešimt ar net keliais šimtais akcijų. Norėdami susiaurinti stebimų akcijų kiekí, reikalingi 
objektyvus klasifikavimo, rangavimo modeliai. Pasinaudodami akcijų rangavimo sistema, pagrịsta daugybe kriterijų, galima ženkliai sumažinti investuotojo akcijų tyrimo laiką, o sutelkti dèmesị ị konkrečius investavimo sprendimus - pirkti arba parduoti akcijas ir kokiu laiku. Todèl drąsiai galima teigti, kad prekiaujamų akcijų rangavimas yra būtinas elementas ilgalaikei investicinei strategijai. Naudodamiesi finansine kompanijų metrika ir fundamentalia analize galima gauti veiksmingą ižvalgą kurias akcijas verta pirkti ir už kokią kainą. SAW, TOPSIS ir VIKOR modelius galima lengvai pritaikyti akcijų rangavimui ir pasirinkimui pagal ịvairias investicines strategijas, kas ir bandoma parodyti šiame tyrime.

Manoma, kad investuotojų elgseną galima pagrịsti elgsenos finansų teorija, kuri šiuolaikiniame pasaulyje turi vis didesnę reikšmę. Elgsenos finansu teorija - tai mokslas apie tai, kaip psichologiniai veiksniai daro ịtaką sprendimų prièmimui finansų rinkose bei organizacijose (Bikas ir Kavaliauskas, 2010). Finansų elgesio mokslas tiria finansų rinkų neveiksmingumo priežastis ir padarinius: iš kur atsiranda rinkos neefektyvumas ir kodèl jis apskritai egzistuoja, taip pat kodėl paprasti investuotojai linkę daryti klaidas. Elgsenos finansų teorija remiasi dviem idèjomis (Gudelytė ir Valužis, 2012):

- Arbitražo ribotumo idejja. Ši ribotumo idejja padeda išsiaiškinti kad naujai gauta informacija ne visuomet gali paveikti akcijų kainas.

- Investuotojų iracionalumo ideja. Teikiama pirmenybė investuotojų norams ir ịsitikinimams.

Šios dvi aukščiau paminètos idèjos papildo vieną kitą ir leidžia prognozuoti akcijų kainų kryptị bei jų grąžą. Didžiulių nuostolių ir klaidų finansų rinkos dalyviai galètų išvengti atsižvelgiant ị rizikos šaltinius (Jajuga, 2009):

1. Didelis įsitikinimas - atsirandantis dèl pasitikèjimo savo igūdžiais, ypatingai tada, kai pasiekiama sèkmė investuojant. Tokiu atveju investuotojas dažnai priima iracionalius sprendimus neįvertinęs ir nepakankamai išanalizavęs rinkos situacijos;

2. Nerealus optimizmas - apima didelę reikšmę optimistiškai informacijai, kuri pateisina investuotojo sprendimą, neatkreipiant dėmesio ì perspejjančią informaciją, kuri neigia investuotojo sprendimo teisètumą;

3. Pasitikejjimas tendencija akcijų rinkoje - grindžiama ịsitikinimu, kad vykstanti kainų akcijų tendencija, nepriklausomai nuo to ar ji mažèjanti, ar didèjanti, tęsis.

4. Aukštas vertinimo konservatyvumas - reiškia, jog investuotojas yra pernelyg prisirišęs prie iki šiol taikytų taisyklių, kurios kintančioje rinkoje gali būti pasenusios.

Galima išvardinti keletą svarbių teigiamų profesinių ,treiderio“ savybių. Pirma, investuotojas neturètų siekti tikslo - kontroliuoti visą rinką. Antra, jis turi žinoti maksimalią riziką, kurią yra pasirengęs prisiimti. Trečia, profesionalus rinkos dalyvis neturètų prisirišti prie jam jau gerai žinomų finansinių instrumentų. Ketvirta, investuotojas turi sugebèti numatyti keletą plètros scenarijų rinkoje ir jei reikia, teikti pirmenybę ilgalaikiai perspektyvai, o ne pelnui, kurị šiuo metu galima gauti. Penkta, norint pasiekti gerų rezultatų prekiaujant vertybinių popierių biržoje, reikia turèti ịgūdžių apdoroti reikiamos informacijos srautus.

Aukščiau paminètos savybès padeda sumažinti klaidų skaičių ir palengvina investuotojo mąstymą bei skatina ji pati elgtis racionaliai. Šios elgesio finansų teorijos yra pritaikomos praktikoje, nes jos leidžia paaiškinti daugeli kitų investuotojų veiksmus ir net juos numatyti. Kitaip tariant, leidžia kurti sėkmingos investavimo rinkoje finansines strategijas, tinkamu metu įeiti ir išeiti iš rinkos.

\section{Metodologija}

Investuotojų elgesys rinkos ekonomikoje pabrèžia, kad individualius sprendimus motyvuoja investuotojų privatūs finansiniai interesai, o veiksmų koordinavimas priklauso nuo finansinių resursų dydžio. Todèl priimant atitinkamą sprendimą, investuotojas turètų pasižymèti savo racionalumu. Dažnu atveju, spręsdamas portfelio sudèties pasirinkimo problemą, profesionalūs kapitalo rinkos dalyviai naudoja kiekybinius daugiakriterinius metodus (MCDM) (Satty, 2008).

V. Podvezko ir A. Podviezko savo straipsnyje „Kriterijų reikšmingumo nustatymo metodai“ (2014) pažymi, jog kiekybinių daugiakriterinių metodų tikslas yra nustatyti geriausią iš lyginamų alternatyvų arba ranguoti jas pagal svarbumą vertinimo tikslo atžvilgiu. Ieškant palankiausių sprendimų pasirenkant investicinius instrumentus taikysime SAW, TOPSIS ir VIKOR metodus. Tyrimui atrinktos penkios pasaulinès pirmaujančios technologinès įmonès, kurių akcijomis prekiaujama Jungtinèse Amerikos Valstijose, NASDAQ biržoje. Imonių finansinei veiklai ìvertinti pasirinkti dažniausiai naudojami rodikliai: pelningumo rodiklis (angl. Net Profit Margin), bendrasis likvidumo rodiklis (angl. Current Ratio), kritinis likvidumo rodiklis (angl. Quick ratio TTM), veiklos rodikliai: turto pelningumo rodiklis (angl. ROA) bei nuosavo kapitalo pelningumo rodiklis (angl. $R O E$ ). Kadangi tyrimui pasirinkti finansiniai rodikliai yra vienodai reikšmingi, atrinktiems penkiems svarbiausiems kriterijams suteikiami vienodi svoriai. Svorių suma mūsų tyrime turi sudaryti vienetą, todèl kiekvieno kriterijaus svoris lygus - 0,2. Pasitelksime ị finansinę analizę, taip pat ị fundamentaliosios analizes elementus tam, kad priimti pagrịstą sprendimą - kokią akciją įtraukti formuojant investicinị portfelį.

Vienas paprasčiausių ir dažniausiai naudojamų daugiakriterinių metodų laikomas paprastasis adityvusis svorinis (angl. SAW - Simple Additive Weighting) metodas (Churchman ir Ackoff, 1954). Pagrindinis šio metodo 
principas tas, kad kiekvienam sprendimo variantui reikia nustatyti standartizuoto sprendimo matricos linijinių elementų ir atitinkamų svorio vektoriaus elementų derinį (Abdullah ir Adawiyah, 2013). Tai suteikia galimybę išdèstyti variantus ir nurodyti galutinį sprendimą pagal priimtus kriterijus. Daugiakriterinio vertinimo SAW metodas prasideda nuo matricos sudarymo. Skaičiuojama visų rodiklių pasvertų normalizuotų reikšmių suma $\mathrm{S}$ kiekvienam j-ajam objektui (Ginevičius ir Podvezko, 2008) taikant šią formulę :

$$
S_{j}^{\mathrm{i}=1}=\sum_{i=1}^{m} w_{i} \dot{r}_{i \tilde{j}},
$$

čia: $w_{-} i-i$-tojo kriterijaus svoris; $r_{-}^{-} i j-$ normalizuotas $j$-ojo objekto $i$-tojo kriterijaus reikšmės; $i=1, \ldots, m$; $j=1, \ldots, n ; m$ - kriterijų skaičius; $n$ - objektų / alternatyvų skaičius.

Mūsų tyrime siekiame maksimumo, todèl prieš matricos normalizavimą, įvertiname, kuri kiekvieno kriterijaus vertė yra geriausia. Kiekvieno kriterijaus esamą reikšmę daliname iš kiekvieno kriterijaus geriausios reikšmès ir gauname normalizuotą matricą. Dauginant rodiklių reikšmingumą iš gautos normalizuotos sprendimų matricos elementų, sudarome svertinę normalizuotą matricą. Susumuojame kiekvieno kriterijaus reikšmes ir atliekame rangavimą (Kacprzak ir Rudnik, 2015).

Kitas metodas, kurị taikysime darbe - Prioriteto nustatymo pagal artumo idealiajam taškui kriterijų metodas (angl. TOPSIS). TOPSIS metodas prasideda nuo pirminių duomenu analizès ir matricos sudarymo, priskiriant kiekvienai alternatyvai kriterijų reikšmes (Balioti et al., 2018; Kacprzak 2018). Pirminè matrica, taip pat kaip ankstesniame metode susideda iš penkių alternatyvų (technologinių įmonių akcijų), kuri aprašyta penkiais tais pačiais finansiniais rodikliais kaip ir pirmajame metode. Atrinktiems penkiems svarbiausiems kriterijams suteikiami vienodi svoriai - 0,2. Norint lyginti skirtingus matmenis, sekančiu žingsniu pradinius matricos duomenis perskaičiuojame ị apibrèžtus, t. y. normalizuojame matricą. TOPSIS metode, sprendimų matrica normalizuojama taikant vektorinès normalizacijos formulę (Simanavičienè, 2016).

$$
n_{i j}=\frac{x_{i j}}{\sqrt{\sum_{i=1}^{m} x_{i j}^{2}}},
$$

čia: $n_{i j}$ - normalizuota matrica; $i=1, \ldots, m ; j=1, \ldots, m ; x_{i j}$ - rodikliai.

Gavus normalizuotą matricą, atliekame papildomus veiksmus. Apskaičiuojame ir suformuojame svertinę normalizuotą matricą. Pasverta normalizuota matrica skaičiuojama kiekvieną normalizuotos matricos elementą padauginus iš atitinkamo rodiklio reikšmingumo (Bulgurcu, 2012). Taikome žemiau esančią formulę:

$$
v_{i j}=w_{j} n_{i j}, \operatorname{kur} i=1, \ldots, m ; j=1, \ldots, n,
$$

čia: $v_{i j}$ - pasverta normalizuota matrica; $w_{j}$-j-ojo kriterijaus svoris; $n i j$ - normalizuotos matricos elementas.

Maksimizuojantys kriterijai mūsų tyrime tai grynasis pelnas, bendrasis likvidumo rodiklis, turto pelningumas ir nuosavo kapitalo pelningumo rodiklis. Prie minimizuojančių kriterijų priskiriame bendrajj likvidumo rodiklį. Turint svertinę normalizuotą matricą, apskaičiuojame idealų teigiamą bei idealų neigiamą sprendimą, kuris nustatomas taikant šias formules:

$$
\begin{gathered}
V^{+}=\left(v_{1}^{+}, v_{2}^{+}, \ldots, v_{n}^{+}\right)=\left(\left(\max _{i} v_{i j} \mid j \in I\right),\left(\min _{i} v_{i j} \mid j \in J\right)\right) ; \\
V^{-}=\left(v_{1}^{-}, v_{2}^{-}, \ldots, v_{n}^{-}\right)=\left(\left(\min _{i} v_{i j} \mid j \in I\right),\left(\max _{i} v_{i j} \mid j \in J\right)\right) .
\end{gathered}
$$

Apskaičiavus idealų teigiamą bei idealų neigiamą sprendimą, galime suskaičiuoti atstumus Euklido erdvėje iki idealaus teigiamo ir idealaus neigiamo sprendimų, vadovaudamiesi šiomis formulèmis:

$$
\begin{gathered}
S_{i}^{+}=\sqrt{\sum_{j=1}^{n}\left(v_{i j}-v_{i}^{+}\right)^{2}}, i=1,2, \ldots, m ; \\
S_{i}^{-}=\sqrt{\sum_{j=1}^{n}\left(v_{i j}-v_{i}^{-}\right)^{2}}, i=1,2, \ldots, m .
\end{gathered}
$$

Suskaičiavus vektorių atstumus Euklido erdvèje iki idealaus teigiamo ir idealaus neigiamo sprendimų, remdamiesi apačioje pateikta formule, skaičiuojame santykini kiekvienos alternatyvos artumą (naudingumą) idealiajam variantui: 


$$
P_{i}=\frac{S_{i}^{-}}{S_{i}^{-+S_{i}^{+}}}
$$

Jeigu $P_{i}$ reikšmė bus artima vienetui, tuo i-asis variantas bus artimesnis $\mathrm{V}+$, tai reiškia jog, geriausia alternatyva bus ta, kurios kompanijos akcijos Pi reikšmė bus didžiausia (Ustinovičius ir Zavadskas, 2004). Tam, kad tuo įsitikintume, atliekame skaičiavimus ir suranguojame tirtus objektus.

Trečiasis tyrime naudojamas metodas - kompromisinis klasifikavimo (VIKOR - srb. VIseKriterijumska Optimizacija ir Kompromisno Resenje) metodas (Oprikovič, 1998). Šio metodo idejja - išmatuoti tiriamo varianto atstumą nuo idealaus sprendinio varianto ir pasiūlyti tinkamiausias alternatyvas, jeigu vertinimo kriterijai yra prieštaringi (Piwowarski et al., 2018). Šis modelis turi panašumų su TOPSIS modeliu ir yra naudinga taikymo priemonè tais atvejais, kai sprendimų prièmejas nesugeba nustatyti savo pasirinkimo pradiniame sprendimo etape. VIKOR metodas naudojamas atrinkti objektus ir juos reitinguoti. Metodo skaičiavimo procedūrą sudaro šie skaičiavimo veiksmai (Tzeng ir Liou, 2012). Pirmuoju žingsniu, vadovaudamiesi žemiau esančia formule, nustatome idealaus teigiamus ir idealaus neigiamus taškus:

$$
\begin{gathered}
f_{i}=\max _{j\{F i j\}} f_{i}^{-=\min _{j\{F i j\}}} \text { jeigu } i \text {-oji funkcija reiškia naudą. } \\
f_{i}=\min _{j\{F i j\}} f_{i}^{-=\max _{j\{F i j\}}} \text { jeigu } i \text {-oji funkcija reiškia sąnaudas. }
\end{gathered}
$$

$\operatorname{Kur} j=1,2, \ldots, \mathrm{m}$.

Atlikus pirmuosius skaičiavimus, antruoju žingsniu surandame kiekvieno objekto vidutinio svertinio atstumą nuo idealaus taško $S_{i}$

$$
\begin{gathered}
S_{i}=\sum_{i=1}^{n} w\left[\frac{(f i j) \max -(f i j)}{(f i j) \max -(f i j) \min }\right] \text { išreiškiant naudą } \\
S_{i}=\sum_{i=1}^{n} w\left[\frac{(f i j)-(f i j) \min }{(f i j) \max -(f i j) \min }\right] \text { išreiškiant sąnaudas }
\end{gathered}
$$

ir didžiausio svertinio atstumo nuo idealaus taško $R j$ apskaičiavimas

$$
\begin{aligned}
& R_{j}=\max \left\{w\left[\frac{(f i j) \max -(f i j)}{(f i j) \max -(f i j) \min }\right]\right\} \text { išreiškiant naudą } \\
& R j=\max \left\{w\left[\frac{(f i j)-(f i j) \min }{(f i j) \max -(f i j) \min }\right]\right\} \text { išreiškiant sąnaudas }
\end{aligned}
$$

Su sekančiais žingsniais, apskaičiuojame kiekvieno objekto $Q j$ charakteristikos reikšmes:

$$
Q_{j}=q \frac{S_{j}-\min S_{k}}{\max S_{k}-\min S_{k}}+(1-q) \frac{R_{j}-\min R_{k}}{\max R_{k}-\min R_{k}},
$$

čia: $q$ - parametras, apibūdinantis vidutinès ir didžiausios matavimo vertès santykị. Dažniausiai naudojamas 0,5 koeficientas (Cristóbal, 2010).

Remiantis VIKOR metodu, atkreipiame dėmesị - kuo mažesnis koeficientas, tuo aukštesnè pozicija reitinge. Pasirenkant pirmaji variantą iš indekso reitingo ir lyginant ji su iškart po jo einančiu variantu, šiame etape tikrinamos dvi sąlygos : priimtinas pranašumas ir priimtinas sprendimų stabilumas. Remiantis gauta informacija nusprendžiama kuris variantas yra laikomas kompromisiniu sprendimu.

\section{Investicinių strategijų taikymas kapitalo rinkoje}

Praktinejje darbo dalyje, ieškant palankiausių investavimo sprendimų alternatyvų, pritaikytas SAW metodas. Tyrimui atrinktos penkios pasaulinès didžiausios technologijų sektoriaus įmonès, ịtrauktos ị NASDAQ biržos sąrašą, atsižvelgiant i jų rinkos kapitalizacijos dydį bei akcijų prekybos duomenis (Financial Visualizations). Remiantis bendrovių metinių ataskaitų duomenimis, nagrinejjami finansiniai duomenys - paskutinių penkerių metų (2015-2019 m.) vidurkiai (CSIMarket). Turimus vidurkius panaudojame pradinei duomenų matricai paruošti $5 \times 5$ (2 lentelè). 
2 lentelè. Finansinių įmonių veiklos duomenys SAW metodui (proc.) (sudaryta autorių, remiantis Financial Visualizations duomenimis)

\begin{tabular}{|c|c|c|c|c|c|}
\hline $\begin{array}{c}\text { Platinimo } \\
\text { akcijomis įmone }\end{array}$ & $\begin{array}{c}\text { Grynasis } \\
\text { pelnas }\end{array}$ & $\begin{array}{c}\text { Bendrasis likvidumo } \\
\text { rodiklis }\end{array}$ & $\begin{array}{c}\text { Kritinis likvidumo } \\
\text { rodiklis }\end{array}$ & $\begin{array}{c}\text { Turto pelningumo } \\
\text { rodiklis }\end{array}$ & $\begin{array}{c}\text { Nuosavo kapitalo } \\
\text { pelningumo rodiklis }\end{array}$ \\
\hline AMAT & 17,03 & 2,70 & 1,35 & 13,12 & 28,16 \\
\hline CSCO & 16,54 & 1,50 & 2,01 & 7,53 & 16,27 \\
\hline CTSH & 12,36 & 2,60 & 1,55 & 11,74 & 16,61 \\
\hline INTC & 20,79 & 1,50 & 0,51 & 11,43 & 19,47 \\
\hline SWKS & 25,23 & 5,60 & 2,71 & 20,73 & 23,74 \\
\hline
\end{tabular}

Kadangi siekiame maksimumo, nustatome geriausias kriterijų reikšmes ir normalizuojame matricą (3 lentelè).

3 lentelè. Normalizuota matrica taikant SAW metodą (sudaryta autorių)

\begin{tabular}{|c|c|c|c|c|c|}
\hline $\begin{array}{c}\text { Platinimo } \\
\text { akcijomis įmone }\end{array}$ & $\begin{array}{c}\text { Grynasis } \\
\text { pelnas }\end{array}$ & $\begin{array}{c}\text { Bendrasis likvidumo } \\
\text { rodiklis }\end{array}$ & $\begin{array}{c}\text { Kritinis likvidumo } \\
\text { rodiklis }\end{array}$ & $\begin{array}{c}\text { Turto pelningumo } \\
\text { rodiklis }\end{array}$ & $\begin{array}{c}\text { Nuosavo kapitalo } \\
\text { pelningumo rodiklis }\end{array}$ \\
\hline AMAT & 0,675 & 0,482 & 0,498 & 0,633 & 1 \\
\hline CSCO & 0,656 & 0,268 & 0,742 & 0,363 & 0,578 \\
\hline CTSH & 0,490 & 0,464 & 0,572 & 0,566 & 0,590 \\
\hline INTC & 0,824 & 0,268 & 0,188 & 0,551 & 0,691 \\
\hline SWKS & 1 & 1 & 1 & 1 & 0,843 \\
\hline
\end{tabular}

Pasižiūrèję i turimą normalizuotą matricą, peršasi mintis, jog protingiausia būtų investuoti i Skyworks Solutions (SWKS) akcijas. Pasitikrinimui, sudarome svertinę normalizuotą matricą, susumuojame kiekvieno kriterijaus reikšmes ir atliekame rangavimą (4 lentelè).

4 lentelè. Svertinè normalizuota sprendimų matrica SAW metodas (sudaryta autorių)

\begin{tabular}{|c|c|c|c|c|c|c|c|}
\hline $\begin{array}{c}\text { Platinimo } \\
\text { akcijomis } \\
\text { imone }\end{array}$ & $\begin{array}{c}\text { Grynasis } \\
\text { pelnas }\end{array}$ & $\begin{array}{c}\text { Bendrasis } \\
\text { likvidumo } \\
\text { rodiklis }\end{array}$ & $\begin{array}{c}\text { Kritinis } \\
\text { likvidumo } \\
\text { rodiklis }\end{array}$ & $\begin{array}{c}\text { Turto } \\
\text { pelningumo } \\
\text { rodiklis }\end{array}$ & $\begin{array}{c}\text { Nuosavo kapitalo } \\
\text { pelningumo } \\
\text { rodiklis }\end{array}$ & Rezultatas & Rank \\
\hline AMAT & 0,135 & 0,096 & 0,100 & 0,127 & 0,200 & 0,658 & 2 \\
\hline CSCO & 0,131 & 0,054 & 0,148 & 0,073 & 0,116 & 0,522 & 4 \\
\hline CTSH & 0,098 & 0,093 & 0,114 & 0,113 & 0,118 & 0,536 & 3 \\
\hline INTC & 0,165 & 0,054 & 0,038 & 0,110 & 0,138 & 0,505 & 5 \\
\hline SWKS & 0,200 & 0,200 & 0,200 & 0,200 & 0,169 & 0,969 & 1 \\
\hline
\end{tabular}

Taikant SAW metodą ir atlikus akcijų analizę, galime nustatyti, kad akcija Skyworks Solutions (SWKS) yra mūsų ieškomas investavimo sprendimas. Atliktas tyrimas parodo, kad SAW metodas, kuri lengviau naudoti, pasižymi savo skaičiavimo paprastumu ir gautų rezultatų aiškumu.

Taikant sekantị, TOPSIS metodą, panaudojame jau turimus vidurkius pradinès matricos sudarymui (3 lentelè). Vadovaudamiesi šio metodo nurodytais žingsniais ir atlikus skaičiavimus - mūsų TOPSIS metodo geriausia alternatyva bus ta, kurios kompanijos akcijos 5 lentelèje gauta $P_{i}$ reikšmè bus didžiausia.

5 lentelè. Kompanijų akcijų rangavimas TOPSIS metode (sudaryta autorių, remiantis Kraujaliené, 2019)

\begin{tabular}{|c|c|c|c|c|}
\hline Platinimo akcijomis ịmone & Si+ & Si- & Pi & Rank \\
\hline AMAT & 0,112 & 0,101 & 0,474 & 2 \\
\hline CSCO & 0,182 & 0,04 & 0,182 & 5 \\
\hline CTSH & 0,140 & 0,072 & 0,339 & 4 \\
\hline INTC & 0,138 & 0,121 & 0,468 & 3 \\
\hline SWKS & 0,112 & 0,160 & 0,589 & 1 \\
\hline
\end{tabular}

Atsižvelgiant i gautus rezultatus, galime teigti, kad geriausia šiuo atveju investuoti i SWKS (Skyworks Solutions) bendrovės akcijas. Pritaikant TOPSIS metodą, šios kompanijos rezultatai yra arčiausiai idealaus sprendimo, kurių naudingumo verte sudaro 0,58 ir užima geriausią - pirmą poziciją galutinèje lentelëje. Blogiausiai ivvertinta liko CSCO (Cisco Systems) kompanija, kuri liko paskutineje pozicijoje - 0,182. Neabejotinai, sprendimas 
investuoti i šios kompanijos akcijas yra labiau artimesnis antiidealiniam sprendimui. Pagal pritaikytą metodą, CSCO akcijos igijo mažiausią naudą nagrinèjamos problemos poreikiams, o SWKS - didžiausią naudą.

Trečiasis taikomas metodas - VIKOR. Tuo pačiu principu kaip SAW ir TOPSIS metodais, turint mūsų pirminę matricą (3 lentelè) atliekame finansinę ịmonių veiklos analizę.

6 lentelè. Kompanijų akcijų rangavimas VIKOR metode (sudaryta autorių)

\begin{tabular}{|c|c|c|c|c|c|c|c|c|c|}
\hline $\begin{array}{c}\text { Platinimo } \\
\text { akcijomis } \\
\text { imone }\end{array}$ & $\begin{array}{c}\text { Grynasis } \\
\text { pelnas }\end{array}$ & $\begin{array}{c}\text { Bendrasis } \\
\text { likvidumo } \\
\text { rodiklis }\end{array}$ & $\begin{array}{c}\text { Kritinis } \\
\text { likvidumo } \\
\text { rodiklis }\end{array}$ & $\begin{array}{c}\text { Turto } \\
\text { pelningumo } \\
\text { rodiklis }\end{array}$ & $\begin{array}{c}\text { Nuosavo } \\
\text { kapitalo } \\
\text { pelningumo } \\
\text { rodiklis }\end{array}$ & $\begin{array}{c}\text { Svertinis } \\
\text { atstumas nuo } \\
\text { idealaus taško } \\
\mathrm{Sj}\end{array}$ & $\begin{array}{c}\text { Svertinio } \\
\text { atstumo nuo } \\
\text { idealaus taško } \\
\mathrm{Rj}\end{array}$ & Qj & RANK \\
\hline AMAT & 0,13 & 0,14 & 0,12 & 0,12 & 0,00 & 0,51 & 0,14 & 0,57 & 2 \\
\hline CSCO & 0,14 & 0,20 & 0,06 & 0,20 & 0,20 & 0,80 & 0,20 & 1,00 & 5 \\
\hline CTSH & 0,20 & 0,15 & 0,11 & 0,14 & 0,19 & 0,78 & 0,20 & 0,99 & 4 \\
\hline INTC & 0,07 & 0,20 & 0,20 & 0,14 & 0,15 & 0,76 & 0,20 & 0,97 & 3 \\
\hline SWKS & 0,00 & 0,00 & 0,00 & 0,00 & 0,07 & 0,07 & 0,07 & 0,00 & 1 \\
\hline
\end{tabular}

Remiantis šeštos lentelès apskaičiuotomis vertėmis pagal principą - kuo mažesnis koeficientas, tuo aukštesnè pozicija reitinge. Pastebime, jog pritaikius VIKOR metodą mūsų skaičiavimams, sprendimas investuoti ị Skyworks Solutions (SWKS) akcijas būtų tinkamiausias. Iracionalus sprendimas investuoti savo turimas lèšas būtų ị JAV tarptautinès Cisco bendrovès akcijas, kuri atsidūre paskutiniojoje - penktoje vietoje.

\section{Išvados}

Mokslinėje literatūroje aptariama daugybę metodų ir priemonių, skirtų spręsti sprendimų prièmimo procesus. Kelių kriterijų sprendimų prièmimo procese, nutarimą priimantis asmuo susiduria su sunkumais: reikia palyginti kelis sprendimų variantus, apibūdinančius daugybę kriterijų, kurie dažnai prieštarauja vienas kitam. Atliktas tyrimas apėmė technologinio sektoriaus biržoje kotiruojamų akcijų pasirinkimo problematiką. Analizuojamas laikotarpis: 2015-2019 m. įmonių finansinès veiklos rodiklių vidurkiai. Atliekant analizę, buvo atsižvelgta ị penkis rodiklius, apibūdinančius įmonių ekonominę ir finansinę raidą. Atsižvelgiant ị technologinių ịmonių specifiką pasirinkti šie finansiniai rodikliai: grynasis pelnas, bendrasis likvidumo, kritinio likvidumo, turto pelningumo ir nuosavo kapitalo pelningumo rodiklis. Kadangi visi iš aukščiau išvardytų kriterijų yra laikomi vienodai svarbus, tai kiekvieno kriterijaus svoris siekia 0,2. Pateiktas tyrimas leidžia palyginti tris darbe analizuojamus metodus: TOPSIS, SAW ir VIKOR. Išanalizavę gautus rezultatus, pastebime, kad visi svarstomi metodai pateikia vienodą variantų eiliškumą ir nurodo Skyworks Solutions (SWKS) akcijas kaip vieną patraukliausių variantų investavimui. Antrojoje pozicijoje, taikant visus tris nagrinejjamus metodus, kaip galima investavimo alternatyva, pasiliko Applied Materials (AMAT) kompanijos akcijos. Iš tokių pasirinktų bendrovių akcijų sudarytas portfelis gali atrodyti patrauklus investuotojui ilgesnèje perspektyvoje.

Apibendrinant galima teigti, jog neatsižvelgiant i kai kurias abejones (svorio priskyrimas kriterijams, daugiakriterinių metodų pasirinkimas, prioritetinių ekonominių rodiklių nustatymas pagal TOPSIS, SAW ir VIKOR metodus), daugiakriterinių metodų investavimo portfelio sudaryme, turètų padaugèti. Todėl galime daryti prielaidą, kad kiekviena tolesnè analizè, tyrimo metodu taikant daugiakriterinị požiūrị, padeda rasti investicinio instrumento pasirinkimo sprendimo metodą.

\section{Literatūra}

Abdullah, L., \& Adawiyah, R. (2013). Simple additive weighting methods of multi criteria decision making and applications: A decade review. International Journal of Information Processing and Management (IJIPM), 5(1), 39-49.

Balioti, V., Tzimopoulos, C., \& Evangelides, C. (2018). Multi-criteria decision making using TOPSIS method under fuzzy environment. Application in spillway Selection. Proceedings, 2(11), 637. https://doi.org/10.3390/proceedings 2110637

Bikas, E. ir Kavaliauskas, A. (2010). Lietuvos investuotojų elgsena finansų krizès metu. Verslas: teorija ir praktika, 11(4), 370-380. https://doi.org/10.3846/btp.2010.40

Bodie, Z., Kane, A., \& Marcus, A. (2012). Essential of investments. https://www.academia.edu/22031262/Zvi_Bodie_Alex_Kane_Alan_J._Marcus-Essentials_of_Investments-Mc_GrawHill_Irwin_2012_

Bulgurcu, B. (2012). Application of TOPSIS technique for financial performance evaluation of technology firms in Istanbul stock exchange market. Procedia - Social and Behavioral Sciences, 62, 1033-1040. https://doi.org/10.1016/j.sbspro.2012.09.176

Cristóbal, J. R. S. (2010). Multi-criteria decision-making in the selection of a renewable energy project in spain: The Vikor method. Renewable Energy, 36(2), 498-502. https://doi.org/10.1016/j.renene.2010.07.031 
Černius, G. (2013). İmonès finansų valdymo tikslas - tvarumo reikalavimas. Business Systems and Economics, 3(1), 93-105. https://www.mruni.eu/upload/iblock/c0f/008_cernius.pdf

Ginevičius, R. ir Podvezko, V. (2008). Daugiakriterinio vertinimo būdų suderinamumas. Verslas teorija ir praktika: mokslo darbai, 9(1), 73-80. https://doi.org/10.3846/1648-0627.2008.9.73-80

Gudelyte, L. ir Valužis, M. (2012). Investiciju ir pensiju fondu valdymas. Vilnius.

Jajuga, K. (2009). Wprowadzenie do inwestycji finansowych. Depozyty i instrumenty rynku pieniężnego. Warszawa.

Kacprzak, D., \& Rudnik, K. (2015). Porządkowanie wariantów decyzyjnych z wykorzystaniem transformaty Mellina w rozmytej metodzie SAW. Modern Management Review, 20, 69-85. https://doi.org/10.7862/rz.2015.mmr.36

Kacprzak, D. (2018). Przedziałowa metoda TOPSIS dla grupowego podejmowania decyzji. Optimum. Economic Studies, 4(94), 256-273. https://doi.org/10.15290/oes.2018.04.94.19

Kiyak, D. (2014). Individualus investuotojo investavimo alternatyvų vertinimo kriterijų modeliavimas. Buhalterinés apskaitos teorija ir praktika, (16), 114-128. https://doi.org/10.15388/batp.2014.No16.11

Kraujalienė, L. (2019). Comparative analysis of multicriteria decision-making methods evalutating the efficiency of technology transfer. Business, Management and Education, 17(1), 72-93. https://doi.org/10.3846/bme.2019.11014

Markowitz, H. (1952). Portfolio Selection. https://www.math.ust.hk/ maykwok/courses/ma362/07F/markowitz_JF.pdf

Nayman, E. L. (2009). Malaja enciklopedija treydera. Al'fa Kapital.

Niranjan, M. (2013). Sharpe's single index model and its application to construct optimal portfolio: an empirical study. Great Lakes Herald, 7(1). https://pdfs.semanticscholar.org/4630/c94c9c7c54b847694a4154902e97528afba3.pdf

Piwowarski, M., Miłaszewicz, D., Łatuszyńska, M., Borawski, M., \& Kesra, N. (2018). TOPSIS and VIKOR methods in study of sustainable development in the EU countries. Procedia Computer Science, 126, 1683-1692. https://doi.org/10.1016/j.procs.2018.08.109

Podvezko, V. ir Podviezko, A. (2014). Kriteriju reikšmingumo nustatymo metodai. Lietuvos matematikos rinkinys, 55, 111116. https://www.mii.lt/LMR/B/2014/55B21.pdf

Saaty, T. L. (2008). Decision making with the analytic hierarchy process. International Journal of Services Sciences (IJSSCI), 1(1). https://doi.org/10.1504/IJSSCI.2008.017590

Simanavičienė, R. (2016). TOPSIS metodo jautrumas normalizavimo taisyklių atžvilgiu. Lietuvos matematikos rinkinys, 57, 71-76. https://www.semanticscholar.org/paper/TOPSIS-metodo-jautrumas-normalizavimo-taisykliu\%CC\%A8Simanaviciene/c0586d4e1282dec3c333d69764c77ad2aedef2e2

Valakevičius, E. (2008). Investavimas finansų rinkose. KTU leidykla „Technologija“.

Suresh, A. S., \& Harshitha, N. (2017). Comparison of returns and risk using Markowitz and Sharpe's model. International Journal of Management and Commerce Innovations, 5(1), 806-813.

Teplova, T. (2011). Investitsii. Yurayt.

Tzeng, G., \& Liou, J. (2012). Comments on "Multiple Criteria Decision Making (MCDM) methods in economics: An overview". Technological and Economic Development of Economy, 18(4), 672-695. https://doi.org/10.3846/20294913.2012.753489

Ustinovičius, L. ir Zavadskas, E. K. (2004). Statybos investiciju efektyvumo sistemotechninis įvertinimas. VGTU leidykla „Technika“.

Valentinavičius, S. (2010). Investiciju valdymas: teoriniai ir praktiniai aspektai. Vilniaus universiteto leidykla.

Wells Fargo Bank. (2019). Active versus passive investing. https://www.abbotdowning.com/_asset/jnq16k/Active-VersusPassive-Investing.pdf

Zaytseva, N. (2014). Upravlenie investitsiyami. http://www.brsu.by/sites/default/files/ecoperate/upravlenie_investiciyami.pd

\title{
APPLYING INVESTMENT STRATEGIES IN THE CAPITAL MARKET
}

\author{
Grigorij ŽILINSKIJ, Monika GEIGAL
}

\begin{abstract}
Article describes investment concept and provides classification, indicates investors' types by providing generalized definition on investment. Pointing that rational decisions are hard to make for not - experienced/beginner investors. Therefore, passive and active investment strategies are described. Article covers their pros and cons. Risk and return are key elements within investment process. Following actions are must if aiming to invest successfully define goal, evaluate situation, measure resources, define feasible alternatives. Investors' behaviour could be justified by financial behaviour theory, which is highly recognizable these days. Moreover, it is important to notice investors' requirements and financial capabilities. Best possible investment strategy selected for the research purposes and multi - criteria evaluation methods used (SAW, TOPSIS, VIKOR) defining most profitable investment model.
\end{abstract}

Keywords: investment, investment portfolio, investment strategies, capital market, active investing, passive investing, alternatives to the solution. 